\title{
Brainstorming Technique In Teaching Writing Descriptive Text
}

\author{
Febri Anggraini \\ MTs YPI Darul Huda Lubuk Harjo \\ ”febrianggraini60@gmail.com
}

\begin{abstract}
This study investigated the effect of the brainstorming technique to Increase Students' Writing Skill at the Tenth Grade of MA YPI Darul Huda Lubuk Harjo. The objective of the study was to find and describe whether there any significant difference between students who are taught by using brainstorming techniques and the students who are taught by using the conventional technique to teach writing skills at the tenth grade of MA YPI Darul Huda Lubuk Harjo. Therefore, for this study writer used quasi-experimental design as the method. The population was 158 and for sample 58 students, a sample of this study used purposive sampling. In this study, the writer was collecting the data used a written test as an instrument, and it was analyzed by an Independent t-test using SPSS 16 , the result showed that $\mathrm{t}$-obtained was higher than $t$ table $(6,573>2.000)$, and the value of $s i g(2$ tailed $)=0.00$ less than the value significance level $(0,05)$. It meant that there were any significant differences between the experimental group and the control group. So, the Alternative Hypothesis ( $\mathrm{Ha}$ ) was accepted and Null Hypothesis was rejected. It can be concluded that Brainstorming Technique was significant to increase students' writing skills at the tenth grade of MA YPI Darul Huda Lubuk Harjo.
\end{abstract}

Keywords: Brainstorming Technique, Descriptive Text, Writing Skill.

\section{INTRODUCTION}

According to Seidlhofer (2005:339), English function as a global lingua franca. English is the language of globalization, international communication, commerce and trade, tourism, the media, and culture, that means English is international languages that used every people as tool for communicate with others people from another country. That why English is very important to learn every people in this word. Therefore, as the tool of international communicate, English becomes one of language that must learn of student and also included subject in the school especially in junior and senior high school, even at some boarding school English is the habitual. In learn English there are four skill that student must mastering to make easier.

While, Mckay (2008) say that writing are a both process and product. Its means that writing is a tool of people to sharing about something, the process of writing is about collecting the data, then managing it became a sentence and producing a text. Learn writing in English is important because writing is one of skill that must be mastered by people, especially students. Therefore, student are able to make a good sentence and text. Also, students can share things through good writing skill.

The writer has conducted an interview with teacher in MA YPI Darul Huda Lubuk Harjo, from the interview the writer found several problems in student, they had difficulty in writing. Most of students are not understand about how to write careful and correctly, such as; writing short story, letter, paragraph, and etc, most of them are find confused when search idea for write in some word and also they are less in vocabulary. And from the problems students above, the writer tried to found one technique that can help student in increase their skill in writing, and the technique is brainstorming technique. Brainstorming is technique which attempt student to have critical thinking. As an alternative technique to increase students' writing skill because brainstorming given power to develop their ideas before writing and of course can help them.

Brainstorming is technique which can viewed individual or group engages to critical thinking for give an idea and great solution toward solving their problem (Owo, Idodo, and Ikwut, 2016). When student used brainstorming during solving their problem, they must bring themselves or groups to experience a play with different diverse among them, so they can explore their ideas for the richness 
result. That's mean every student can find better solution to their problem. Because brainstorming is fun, so every student can give idea, and solve their problem in a positive, open minded, and non judgment (Al-Mutairi, 2015). In addition according to Brown (2001), brainstorming as a technique which helps someone initiates some sort of the thinking process. Moreover brainstorming is a quick way to generate a lot of ideas on a subject (Blanchard and Root 2003:41). Based on the explanation, the writer get interested to help student for increase their skill through using Brainstorming technique, so can help student in increasing their writing skill.

\section{Concept of Writing}

According to Siahaan (2008:2), writing is skill of writer to communicated or given about information such as; idea, thought, feeling, and opinion to a reader or group of reader in written form. That means, writing is expressing idea, opinion, story or activities someone into a sentence that form of written with elaborate each other. The function of witting is give information, education or entertainment. In addition, Writing skill is a development process that demands experiences, times, opportunities, training, and ideas that expressed clearly and organized attractively (Taqi, 2015:74). To master in writing cannot learn instance, someone must give all the soul and enjoy when learn it, because writing is not just about a writer, but is about people who read that result in form written. Writing have a process like study, experiences of writer, training and also idea to expressing into a written. And one way to have a good skill in writing is always increase with exercise in writing.

There are five kinds of text must be master, they are; Descriptive Text, Recount text, Narrative Text, Report Text, and the last are Procedure Text (Rugayamana, 2012). From the all kinds of the text descriptive is chosen one by the writer. Descriptive text is one form of written English text which is the writer describes about an object, like: people, thing or place. The object can be an abstract object or concrete object (Siahaan and Shinoda, 2008).

\section{Concept of Brainstorming Technique}

Brainstorming is a technique process of thinking to search an idea or share idea. Brainstorming as a technique which can help someone to initiates some sort of thinking process to search a great idea (Brown, 2001). Its mean that student must start to thinking critical for search a new idea to sharing with someone else and give or taking without fear of being wrong and after get a great idea they can pouring in some form of written, began from some short of thinking and become a bigger idea.

Moreover, brainstorming can gives a students some power to develop their ideas before writing (Kendall and Khuon 2006: 4), that can help the student to increase their skill in writing, because brainstorming give power to develop their ideas before writing, they can give all ideas in another member of group, and of course they can enjoy with their group, and can't lank of word because they give all ideas to be one.

Furthermore, Lang and Evans (2006: 406), brainstorming as a fun, useful, creative thinking technique can be used to begin problem solving. It can be included and done in a group or individual in any lesson. It means that brainstorming is a technique that give access with ideas through in mind either as alone or in a group. The major principle of brainstorming is to let the student give ideas flow without judging them, and always give them spirit to pouring their idea.

\section{METHODOLOGY}

The method of study the writer used quasi-experimental. Cresswel (2012) stated that in the education process, there is a lot of experimental situation that need to use in a group. Quasiexperimental include assignment, but not the random assignment of participants to groups. We can apply the pretest and posttest design approach to a quasi-experimental design. There are two groups which consist of two classes is used as the sample in this design, they are the experimental group and control group. Two groups are given the same materials on the same topics. The experimental group is taught by brainstorming technique, whereas the control group is not taught by brainstorming technique, for the pre-test and post-test to both of class gives before treatment.

There are two kinds of variables, namely the independent variable that influences the other 
variable and the dependent variable that is influenced by the independent variable (Sugiyono 2013: 61). This study consists of two variables, are the dependent and independent variables. The dependent variable is writing skill and the independent variable is brainstorming

The location of this study was a MA YPI Darul Huda. This school is located in Lubuk Harjo, Sumatera Selatan Indonesia. The population was all the student of tenth-grade students. For the sample, the writer chooses purposive sampling to determine the sample from the 2 classes, with 29 students in the experimental class and 29 in the control class.

Besides, to determine the students' writing skills the writer used a written test as an instrument. And for analyzing the data by using an independent t-test.

\section{RESULT AND DISCUSSION}

The study was done in six meetings, where the first and last meeting was used for pre-test and post-test. Before the writers were given the treatment in the second meeting, students were given a pre-test for determining their knowledge. After four meetings in treatment, students were given a posttest to know that the brainstorming technique can give an effect on them.

The writer had shown the result of normality, homogeneity, and result of independent T-test that were taken during the research. It is shown in table 1.

Table 1

The Result of Normality, Homogeneity and Independent t-test Experimental and Control Class

\begin{tabular}{|c|c|c|c|c|c|c|c|}
\hline & \multicolumn{7}{|c|}{ Statistical Analysis } \\
\hline & \multicolumn{2}{|c|}{ Normality } & \multirow{2}{*}{$\begin{array}{c}\begin{array}{c}\text { Homoge } \\
\text { neity }\end{array} \\
\text { Levene }\end{array}$} & \multirow[t]{2}{*}{ Sample } & \multicolumn{3}{|c|}{ Independent t-test } \\
\hline & $\begin{array}{l}\text { Kolmogor } \\
\text { ov- } \\
\text { Smirnov }\end{array}$ & Shapiro & & & Sig ( & ed) & $\mathbf{T}$ \\
\hline $\begin{array}{l}\text { Experimental } \\
\text { Class }\end{array}$ & 200 & 091 & \multirow{2}{*}{ 169 } & \multirow{2}{*}{58} & 0,00 & $0,05>$ & \multirow{2}{*}{6,573} \\
\hline Control Class & , 124 & , 185 & & & $\begin{array}{c}\text { Accepted } \\
(\mathrm{HA})\end{array}$ & $\begin{array}{l}\text { Rejected } \\
\text { (HO) }\end{array}$ & \\
\hline
\end{tabular}

Based on table 1, it could be interpreted that teaching writing used brainstorming techniques to enable to get a better score. That means the brainstorming technique was effective to improve students and help them to solve their problem in writing at the tenth grade of MA YPI Darul Huda Lubuk Harjo. It was proved and can be seen from the average score by the result of the Independent t-test of the pre and post-test score in the experimental and control group, the value t-obtain $=6,573$ is higher than $t-$ table-2.000 and the value of sig. (2-tailed) $=0,00$ less than the value of sig. level $(0.05)$ means that the $\mathrm{HA}$ is accepted and Ho is rejected. So, from the data, it was also found that the students can increase their skill in writing trought used Brainstorming Technique. By using the Brainsteoming Technique, can solve their problem.

\section{CONCLUSION}

Based on the findings above, the result independent $t$-test of post-test and pre-test has been conducted systematically, this is based on table 1 that was shown. The implementation of brainstorming gives reaction and effect. From the data, it also found that student can solve their problem in writing since brainstorming techniques are applied in their classrooms. 
74 | Channing: English Language Education and Literature Vol. 5 No. 2 Oktober 2020 Halaman: 71-74

There was no significant difference between a student who was taught by brainstorming technique (experimental group) and students who were taught by conventional technique ( control group). Its means that brainstorming can increase students in writing skill.

\section{REFERENCIES}

Al Mutairi, A. M. (2015), The Effect of Using Bainsrorming Stratrgy in Developing Creative Problem Solving Skills male Students in Kuwait: A Field Study Al-Kharji School in Kuwait City. Journal of Education and Practice, 6.

Blanchard, K. \& Root, C. (2003). Ready to Write: A first Composition Text (Third Edition).New York: Pearson Education, Inc

Brown, H. Douglas. (2001). Teaching by Principles: and Interactive Approach to Language. Pedagogy. New York: Pearson Education

Hellmut R. Lang and David N. Evans. (2006) Models, Strategies, and Methods for Effective Teaching. USA: Longman Person Education, INC.

Kendall, J., and Khuon, O. 2006. Writing Sense: Integrated Reading and Writing Lessons for English Language Learners. United States of America: Stenhouse Publishers.

Mckay, Penny. (2008). Assessing Young Learners. Cambrige: Cambrige University Press.

Owo, D. W., Idode, V. O., \& Ikwut, F, F. (2016). Validity of Brainstorming Strategy on Students' Prior Knowledge and Academic Performance in Chemistry in Selected Secondary Schools in SouthSouth Nigeria. American Scientific Research Journal for Engineering Technology, and Science (ASRJETS)

Sanggam, Siahaan \& Kisno Shinoda. (2008). Generic Text Structure. Yogyakarta: Graha IImu

Seidlhofer, B. (2005). English as a lingua franca. ELT journal, 59(4), 339-341.

Siahaan, Sanggam. (2008). The English paragraph (the first edition). Yogyakarta: Graha Ilmu.

Taqi, Hanan A. et al. 2015. The Effect of Diary Writing on EFL Students' Writing and Language Abilities.UK: British Journal of Education, III (2) 75-91. Retrieved on Saturday, February 3rd 2018. 